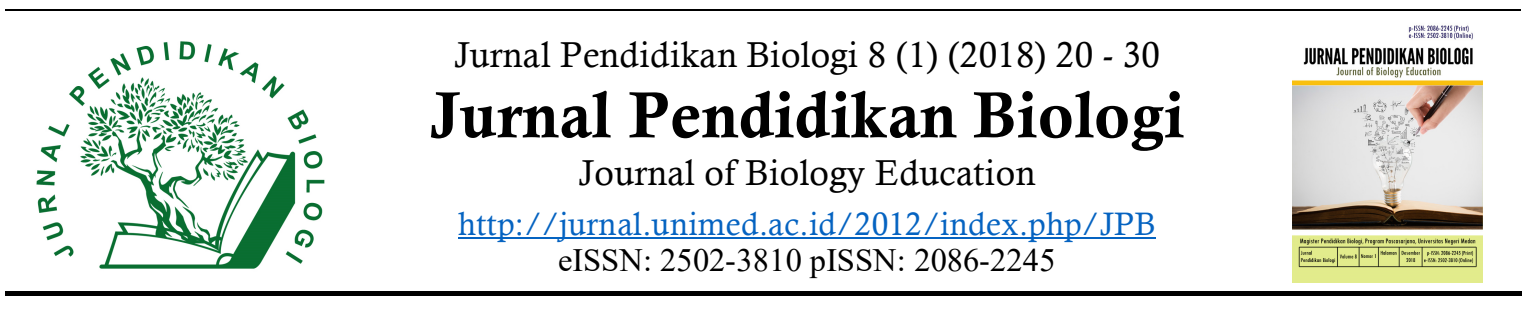

\title{
Penerapan Model Pembelajaran Inkuiri Terbimbing untuk Meningkatkan Kompetensi Siswa dalam Pembelajaran Biologi
}

\author{
Pendrice $^{1, *}$, Evi Suryawati ${ }^{2,{ }^{* *}}$, Suwondo $^{2}$ \\ ${ }^{1}$ Sekolah Menengah Atas Negeri 2 XIII Koto Kampar, Jl. Pasar No.4, Pulau Gadang \\ ${ }^{2}$ Program Studi Pendidikan Biologi FKIP Universitas Riau, Kampus Bina Widya Km 12,5 Simpang Baru Pekanbaru \\ 28293, Indonesia
}

\section{INFO ARTIKEL}

\section{Histori Artikel}

Received 7 Nopember 2018

Revised 8 Desember 2018

Accepted 10 Desember 2018

Published 20 Desember 2018

Keywords:

Grouping Plants,

Guided Inquiry,

Student Competence

\begin{abstract}
Application of guided inquiry learning model to Improve Student Competency in Biology Learning at SMAN 2 XIII Koto Kampar. The purpose of this study was to determine improving student competence of grouping plant. through the application of guided inquiry. This classroom action research was conducted in two cycles, each cycle consisting of planning, implementation, observation and reflection. This study begins with a pre cycle before the cycle I. Subjects were 26 students $X$ IPA 2. Data obtained using the competency attitude instrument observation sheet of religious and social attitudes, including: faithful, honest, discipline, cooperation, tolerance and mutual cooperation. A knowledge data was collected with quiz and test questions at the end of the cycle. The skills data was collected with observation sheets of practices and product. The results showed an increase in the competence of the students after the applied application of guided inquiry learning model. An increase in the average value of attitude competence of the first cycle of 3.15 and the second cycle of 3.49. The competence of knowledge showed an increase from the first cycle of students who pass as many as 22 people $(84.62 \%)$ in the second cycle students who pass as many as 24 people $(92.31 \%)$, while competence of skills to practice skills in the first cycle of 3.16, and the second cycle of 3.30. And then, product skills in the first cycle of 3.04 increased in the second cycle of 3.30 . Implementation guided inquiry can improve students competency in Biology learning.
\end{abstract}

Copyright (C) 2018 Universitas Negeri Medan. Artikel Open Access dibawah lisensi CC-BY-4.0 (https://creativecommons.org/licenses/by/4.0)

How to Cite

Pendrice, Suryawati, E., \& Suwondo (2018) Penerapan Model Pembelajaran Inkuiri Terbimbing untuk Meningkatkan Kompetensi Siswa dalam Pembelajaran Biologi. Jurnal Pendidikan Biologi, 8(1), 20-30.

\section{PENDAHULUAN}

Guru sebagai pemegang kendali pelaksana pembelajaran mempunyai peran yang sangat besar dalam pencapaian tujuan pendidikan, untuk mencapai tujuan pendidikan tidak terlepas dari kompetensi guru dan perencanaan kurikulum yang digunakan. Guru sebagai ujung tombak keberhasilan implementasi kurikulum memiliki persiapan 
yang matang dan siap mengubah paradigma pengajaran. Pembelajaran kurikulum 2013 adalah pembelajaran kompetensi dengan memperkuat proses pembelajaran dan penilaian autentik. Penguatan proses pembelajaran dilakukan melalui pendekatan saintifik, melalui proses inkuiri yang bernapaskan konstruktivisme. Sasaran pembelajaran dengan pendekatan ilmiah mencakup pengembangan ranah sikap, pengetahuan, dan keterampilan yang dielaborasi untuk setiap satuan pendidikan (Hosnan, 2014).

Berdasarkan pengalaman penulis selama menerapkan pembelajaran dengan pendekatan saintifik di SMA Negeri 2 XIII Koto Kampar pada kelas X IPA 2, ditemukan permasalahan yang muncul dalam pembelajaran biologi dengan pendekatan saintifik, pada kompetensi sikap yaitu siswa malu dan takut bertanya, rasa ingin tahu siswa rendah, siswa tidak terbiasa dalam mencari informasi-informasi dan menemukan tentang konsep-konsep pembelajaran karena siswa bekerja secara individu, siswa belum percaya diri dan siswa kurang aktif dalam mencari informasi penunjang, kompetensi pengetahuan termasuk pemahaman konsep dalam belajar rendah sehingga nilai akhir siswa rendah sedangkan kompetensi keterampilan mencakup siswa dalam menyiapkan alat dan bahan, pengamatan dan membuat hasil praktek masih rendah.

Permasalahan dari sisi guru adalah penerapan pendekatan saintifik belum berjalan dengan baik, dimana guru lebih dominan bertanya kepada siswa, guru belum memaksimalkan mendorong dan membimbing siswa, dan guru masih terbiasa dengan memberikan informasi-informasi dengan ceramah tentang materi yang diajarkan, serta kurang memberikan perhatian kepada siswa sebagai fasilitator.

Berdasarkan hasil ulangan harian materi jamur dari 26 siswa, kelas X IPA 2 yang mencapai ketuntasan kompetensi sikap 21 orang siswa atau $80,77 \%$ tuntas, sedangkan 5 orang siswa atau $19,23 \%$ tidak mencapai ketuntasan sedangkan pengetahuan adalah 18 orang siswa atau $69,24 \%$ tuntas sedangkan 8 orang siswa atau $30,76 \%$ tidak mencapai ketuntasan dan keterampilan adalah 21 orang siswa atau $80,77 \%$ tuntas, sedangkan 5 orang siswa atau 19,23\% tidak mencapai ketuntasan.

Berdasarkan permasalahan tersebut, penulis perlu untuk mencarikan solusi pemecahan masalah tersebut agar tidak terulang dan berkelanjutan. Salah satu upaya yang efektif adalah dengan melakukan suatu tindakan kelas melalui perubahan strategi pembelajaran atau model belajar, agar dapat memperbaiki kompetensi siswa. Dalam pembelajaran biologi (teaching on science) yang berkaitan dengan kerja ilmiah, adalah sangat tepat jika guru memilih dan menerapkan metode inquiry. Untuk materi tertentu, guru perlu memberikan kesempatan pada siswa untuk mengembangkan rasa ingin tahunya dan memberikan peluang pada mereka untuk menemukan sendiri jawaban atas rasa keingintahuan siswa pada alam; bukan justru membunuh keingintahuan siswa, atau bahkan menuntut hanya satu cara dalam menemukan jawaban atas persoalan sains (Bruce, 2001). Namun demikian, untuk menumbuhkan keingintahuan dan keterampilan siswa menemukan berbagai jawaban atas pertanyaan -pertanyaan ini, guru perlu memberikan bimbingan (guided), terlebih pada siswa yang belum biasa melakukan langkah-langkah kerja ilmiah ini.

Namun disisi yang lain, pada usia menjelang dewasa ini, siswa SMA dipandang masih memerlukan bantuan dan bimbingan guru dalam melakukan berbagai kegiatan belajar, terutama dalam kaitannya dengan pembangunan pengetahuan dan pemahaman mereka. Bagaimana menangkap permasalahan dari suatu fakta atau gejala biologi, bagaimana merumuskan permasalahan ini, sampai 
dengan bagaimana menemukan pemecahan permasalahan, khususnya siswa SMAN 2 XIII Koto Kampar, masih perlu dibimbing guru. Dalam posisi yang demikian, Paidi (2009) melihat penggunaan guided inquiry dalam pembelajaran sains sangat tepat. Dengan strategi ini, siswa dibimbing oleh guru dalam membangun pengetahuan dan pemahaman mengenai objek dan persoalan sains, termasuk proses-proses sains terkait, dan secara perlahan guru membekali mereka untuk mampu melakukan belajar mandiri (termasuk melakukan investigasi secara mandiri). Materi yang dapat menggunakan dengan model mencari dan menemukan (inquiry) untuk meningkatkan kompetensi siswa adalah materi klasifikasi atau pengelompokkan divisio tumbuhan.

Proses pembelajaran pada Kurikulum 2013 untuk semua jenjang dilaksanakan dengan menggunakan pendekatan ilmiah (scientific). Karakteristik pembelajaran dengan pendekatan saintifik adalah berpusat pada siswa, melibatkan keterampilan proses sains dalam mengonstruksi konsep, hukum atau prinsip, melibatkan proses-proses kognitif yang potensial dalam merangsang perkembangan intelek, khususnya keterampilan berpikir tingkat tinggi siswa dan mengembangkan karakter siswa (Hosnan, 2014).

Selanjutnya Hosnan (2014) kompetensi dimunculkan dengan harapan agar siswa mampu menjadi lulusan yang memiliki sikap, pengetahuan dan keterampilan sehingga dia mampu hidup kapan dan dimanapun berada. Berdasarkan Permendikbud No. 81 A Tahun 2013 lampiran IV, proses pembelajaran saintifik terdiri atas lima pengalaman belajar pokok yaitu mengamati, menanya, mengumpulkan informasi, mengasosiasi, dan mengkomunikasikan.

Model-model pembelajaran biologi untuk Kurikulum 2013 yang direkomendasikan berdasarkan kebutuhan pengembangan kom- petensi dan karakteristik materi biologi, diantaranya pembelajaran penemuan/discovery learning/inquiry (Permendikbud No. 65 Tahun 2013).

Pembelajaran inkuiri memberikan kesempatan kepada siswa untuk aktif dan terlibat dalam proses pembelajaran bagaimana menganalisis masalah dengan adil, objektif, kritis, terbuka dan komprehensif serta memberikan pengaruh positif pada sikap ilmiah siswa (Dewi et al, 2013). Natalina et al. (2013) menyatakan model inkuiri terbimbing dapat dijadikan salah satu alternatif model pembelajaran yang dapat membangun sikap ilmiah siswa. Olvah dan Fujianor (2015) menunjukkan bahwa penerapan model pembelajaran inkuiri terbimbing pada konsep sistem regulasi manusia dapat meningkatkan hasil belajar siswa. Novana et al. (2014) menunjukkan pembelajaran yang menggunakan potensi lokal menumbuhkan keterdekatan ruang dengan siswa sehingga siswa juga dapat langsung untuk mengamati tumbuhan lumut dan tumbuhan paku sesuai dengan kegiatan yang ada dalam modul. Sedangakan penelitian Suprihatin dan hidayah (2014) psikomotor siswa dalam pembelajaran inkuiri terbimbing pada konsep pencemaran lingkungan.

Trianto (2012), inkuiri merupakan bagian inti dari kegiatan pembelajaran berbasis kontekstual. Adapun langkah-langkah kegiatan inkuiri adalah observasi (observation), bertanya (questioning), mengajukan dugaan (hyphotesis), pengumpulan data (data gathering), penyimpulan (conclussion). Pembelajaran dengan mengimplementasikan guided inquiry, pada prinsipnya sama dengan prinsip-prinsip pengimplementasian metode inquiry, namun menuntut peran pembimbingan yang terstruktur.

Tahapan pembelajaran inkuir terbimbing memiliki tahapan-tahapan dalam pembelajaran yaitu: penyajian masalah (confrontation with problem), pengumpulan data (data gathering), 
pengujian data (data experimentation), organisasi data dan formulasi kesimpulan (organizing, formulating and explanation), dan analisis proses inkuiri (analysis of the inquiry proces) (Joyce and Weil, 1992; Wena, 2013; Natalina et al., 2013).

Menurut Putra (2013) tujuan pembelajaran dengan pendekatan inkuiri terbimbing adalah meningkatkan keterlibatan siswa dalam menemukan dan memproses bahan pelajarannya, mengurangi ketergantungan siswa terhadap guru untuk mendapatkan pelajarannya, melatih siswa dalam menggali dan memanfaatkan lingkungan sebagai sumber belajar yang tidak ada habisnya dan memberikan pengalaman belajar seumur hidup.

\section{METODE}

Jenis penelitian yang dilakukan adalah penelitian tindakan kelas (classroom action research), yaitu penelitian reflektif oleh pelaku tindakan yang dilakukan oleh guru sendiri untuk memperbaiki proses pembelajaran yang menjadi tanggung jawabnya. Menurut Arikunto (2012) dalam pelaksanaan penelitian ini mengikuti tahap-tahap penelitian tindakan kelas yang pelaksanaan tindakannya terdiri atas beberapa siklus. Setiap siklus terdiri atas tahap perencanaan (planning), tindakan (acting), pengamatan (observing), dan refleksi (reflecting).

Subjek penelitian ini adalah siswa kelas $\mathrm{X}$ IPA 2 semester II SMA Negeri 2 XIII Koto Kampar dengan jumlah siswa 26 orang yang terdiri dari 13 orang siswa laki-laki dan 13 orang siswa perempuan dengan tingkat kemampuan yang heterogen. Pada penelitian ini peneliti sekaligus guru bidang studi biologi dan teman sejawat yang bertindak sebagai observer guna mengamati seluruh proses belajar mengajar yang berlangsung.

Sumber data dalam penelitian ini terdiri dari beberapa sumber, yaitu siswa, untuk mendapatkan data tentang kompetensi belajar siswa dalam kegiatan belajar mengajar dengan menggunakan model pembelajaran inkuiri terbimbing, guru, untuk melihat tingkat keberhasilan implementasi model pembelajaran inkuiri terbimbing untuk meningkatkan kompetensi siswa dalam proses pembelajaran pada materi klasifikasi tumbuhan, dan teman sejawat, untuk melihat implementasi PTK secara komprehensif, baik dilihat dari sisi siswa maupun guru.

Instrumen yang digunakan dalam penelitian ini adalah lembar observasi yang digunakan untuk mengukur sikap adalah pengamatan sikap religius dan sikap sosial meliputi beriman, jujur, disiplin, kerjasama, toleransi dan gotong royong, sedangkan lembaran observasi keterampilan siswa adalah kegiatan praktek. Tes dilakukan untuk mengukur kompetensi belajar siswa diberikan setelah pembelajaran setiap pertemuannya yaitu berupa soal post tes dan ulangan harian pada akhir setiap siklus. Lembar catatan lapangan ini memuat kondisi siswa pada saat kegiatan belajar mengajar berlangsung dan tindakan guru dalam melaksanakan pembelajaran.

\section{Analisis Data}

Penilaian kompetensi sikap melalui observasi, meliputi aspek beriman dan bertaqwa kepada Tuhan Yang Maha Esa, jujur, disiplin, kerjasama, toleransi dan gotong royong. Penilaian sikap dilakukan dengan observasi pada saat proses pembelajaran berlangsung. Penilaian pengetahuan siswa untuk menentukan penguasaan konsep siswa terhadap pembelajaran data ini diperoleh melalui tes tertulis. Penilaian kompetensi keterampilan melalui penilaian praktek dan penilaian produk berupa pembuatan herbarium. Penilaian dilakukan dengan membandingkan antara skor perolehan siswa dan skor maksimum (Majid \& Aep, 2014). 
Penelitian ini dikatakan berhasil jika siswa dinyatakan mengalami peningkatan kompetensi sikap, pengetahuan dan keterampilan belajar siswa. Kompetensi pengetahuan (kognitif) dan keterampilan (psikomotor) dengan nilai 2,67 dan sikap (afektif) dengan nilai predikat Baik (Permendikbud No. 104 tahun 2014).

\section{HASIL DAN PEMBAHASAN}

Berdasarkan analisa hasil penelitian menunjukkan, pelaksanaan pembelajaran dengan penerapan model pembelajaran inkuiri terbimbing di kelas X IPA 2 SMA Negeri 2 XIII Koto Kampar dapat meningkatkan kompetensi belajar siswa baik pada kompeten- si sikap, pengetahuan dan keterampilan. Hal ini dibuktikan oleh data yang diperoleh dari prasiklus, siklus I, dan siklus II selama kegiatan penelitian berlangsung. Berikut ini pembahasan masing-masing aspek kompetensi dengan penerapan model pembelajaran inkuiri terbimbing.

\section{Kompetensi Sikap (Afektif)}

Nilai rata-rata kompetensi sikap siswa pada prasiklus adalah 2,79 dengan predikat baik, pada siklus I adalah 3,15 dengan predikat baik, sedangkan pada siklus II diperoleh nilai 3,49 dengan predikat Baik. Nilai rata-rata sikap pada prasiklus, siklus I dan siklus II disajikan pada Tabel 1.

Tabel 1. Nilai rata-rata sikap siswa pada prasiklus, siklus I dan siklus II

\begin{tabular}{llccccc}
\hline \multirow{2}{*}{ No. } & Indikator sikap & \multicolumn{3}{c}{ Rata-rata } & \multicolumn{2}{c}{ Peningkatan } \\
\cline { 3 - 7 } & Pra siklus & Siklus I & Siklus II & Prasiklus ke siklus I & Siklus I ke siklus II \\
\hline 1 & Beriman & 3,08 & 3,83 & 3,95 & 0,75 & 0,12 \\
2 & Jujur & 2,87 & 3,16 & 3,38 & 0,29 & 0,22 \\
3 & Disiplin & 2,97 & 3,19 & 3,51 & 0,22 & 0,31 \\
4 & Kerja sama & 2,92 & 3,06 & 3,42 & 0,14 & 0,36 \\
5 & Toleransi & 2,42 & 2,84 & 3,45 & 0,42 & 0,62 \\
6 & Gotong royong & 2,46 & 2,84 & 3,20 & 0,38 & 0,33 \\
\hline & Rata-rata & 2,79 & 3,15 & 3,49 & 0,37 & \\
\hline & Predikat & Baik & Baik & Baik & & \\
\hline
\end{tabular}

Gambar 1. Perbandingan nilai rata-rata observasi sikap dari prasiklus, siklus I dan siklus II 
Nilai rata-rata tertinggi adalah beriman dan bertaqwa kepada Tuhan Yang Maha Esa disebabkan oleh siswa sudah bersungguhsungguh dalam mengikuti pembelajaran dengan pendekatan inkuiri terbimbing. Siswa juga sudah terbiasa memulai kegiatan pembelajaran dengan mengucapkan salam, dan berdoa. Guru juga pada setiap pembelajaran selalu berusaha mengkaitkan materi dengan menyampaikan nilai-nilai keagungan ciptaan Tuhan.

Berdasarkan observasi sikap religius ini siswa sudah terbiasa melakukan berdoa sebelum dan sesudah belajar dan mengucapkan salam dan guru selalu mengkaitkan pembelajaran dengan kebesaran ciptaan Tuhan. Proses kemanu-siaan sesuai dengan agama sebenarnya adalah proses internalisasi iman, nilai-nilai pengetahuan dan keterampilan dalam konteks mengakui dan mewujudkan nilai-nilai itu dalam amal soleh (Sukanto, 1985; Mustari, 2014).

Nilai rata-rata sikap sosial yang tertinggi adalah sikap disiplin disebabkan siswa hadir, mengerjakan tugas dan mengumpulkan tugas tepat waktunya. Salah satu keberhasilan dari sikap disiplin adalah siswa memiliki motivasi untuk hadir tepat pada waktunya. Dirman \& Juarsih (2014) menyatakan bahwa keteraturan waktu dengan disiplin, dengan adanya disiplin waktu maka akan membina sikap mental yang baik pada diri peserta didik untuk memaknai proses belajar.

Kompetensi sikap gotong royong menunjukkan nilai rata-rata terendah. Penyebab rendahnya nilai sikap gotong royong ini adalah siswa tidak aktif dalam kelompok, tidak melakukan tugas sesuai dengan kesepakatan bersama dan mendahulukan kepentingan pribadi. Dalam proses pembelajaran siswa seharusnya membangun team building yang baik. Dirman \& Juarsih (2014) menyatakan team building (pembentukan tim) akan membantu peserta didik menjadi terbiasa satu sama yang lain atau menciptakan suatu semangat gotong royong dan saling ketergantungan.

Berdasarkan hasil observasi penilaian kompetensi sikap selama menerapkan model pembelajaran inkuiri terbimbing dari prasiklus, siklus I dan siklus II menunjukkan peningkatan. Nilai rata-rata prasiklus 2,79 meningkat pada siklus I menjadi 3,15 dan pada siklus II menjadi 3,49. Penerapan model pembelajaran inkuiri terbimbing pada pokok bahasan klasifikasi tumbuhan seluruh siswa dinyatakan tuntas untuk kompetensi nilai sikap. Hal ini menunjukkan bahwa model inkuiri terbimbing dapat meningkatkan kompetensi sikap siswa. Hal ini sesuai dengan pendapat Yuniastuti (2013) menyatakan bahwa penerapan pembelajaran inkuiri terbimbing juga berdampak pada kenaikan motivasi belajar biologi siswa.

Selanjutnya hasil penelitian Wahyuni (2010) menyimpulkan bahwa pembelajaran menggunakan model pembelajaran inkuiri terbimbing peserta didik menjadi aktif sehingga peserta didik menjadi lebih disiplin, lebih teliti, rasa ingin tahu meningkat dan bekerjasama dengan baik. Selanjutnya diperkuat oleh Natalina et al. (2013) menyatakan model inkuiri terbimbing dapat dijadikan salah satu alternatif model pembelajaran yang dapat membangun sikap ilmiah siswa.

\section{Kompetensi Pengetahuan (Kognitif)}

Berdasarkan analisa data kompetensi pengetahuan jumlah siswa yang tuntas pada prasiklus sebanyak 18 orang dan tidak tuntas sebanyak 8 sedangkan pada siklus I yang tuntas sebanyak 22 orang dan yang tidak tuntas 4 orang. Pada siklus II jumlah siswa yang tuntas meningkat menjadi 24 orang, sedangkan yang tidak tuntas 2 orang. Peningkatan kompetensi pengetahuan seluruh siswa dari prasiklus hingga siklus II disajikan pada Tabel 2. 
Pendrice, et al. / Jurnal Pendidikan Biologi 8 (1) (2018) 20 - 30

Tabel 2. Peningkatan kompetensi pengetahuan dari prasiklus, silkus I dan siklus II

\begin{tabular}{cccccccc}
\hline \multirow{2}{*}{ No } & \multirow{2}{*}{ Data } & \multicolumn{2}{c}{ Prasiklus } & \multicolumn{2}{c}{ Siklus I } & \multicolumn{2}{c}{ Siklus II } \\
\cline { 2 - 8 } & & Jumlah & Persentase & Jumlah & Persentase & Jumlah & Persentase \\
\hline 1 & Tuntas & 18 & $69,23 \%$ & 22 & $84,62 \%$ & 24 & $92,31 \%$ \\
2 & Tidak Tuntas & 8 & $30,77 \%$ & 4 & $15,38 \%$ & 2 & $7,69 \%$ \\
\hline 3 & Rata - rata UH & \multicolumn{2}{c}{2,85} & \multicolumn{2}{c}{3,07} & 3,20 \\
\hline
\end{tabular}

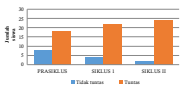

Gambar 2. Perbandingan ketuntasan belajar dari prasiklus, siklus I dan siklus II

Pada Tabel 2 menunjukkan peningkatan kompetensi pengetahuan yang ditinjau dari jumlah siswa yang tuntas dan tidak tuntas berdasarkan nilai tes tertulis diakhir siklus. Dari ketuntasan pengetahuan prasiklus 18 orang tuntas $69,23 \%$ dengan nilai rata-rata $\mathrm{UH}$ 2,85 mengalami peningkatan pada siklus I menjadi 22 orang tuntas $84,31 \%$ dengan nilai rata-rata UH 3,07 pada siklus II menjadi 24 orang 92,31\% dengan nilai rata-rata UH 3,20.

Gambar 2 menunjukkan bahwa ada peningkatan nilai rerata pengetahuan siswa antara prasiklus hingga siklus II. Hal ini dipengaruhi oleh pelaksanaan model pembelajaran inkuiri terbimbing. Sehingga kompetensi pengetahuan siswa semakin meningkat dalam pelaksanaan kegiatan pembelajaran.

Peningkatan kompetensi pengetahuan disebabkan meningkatnya pemahaman siswa dengan melakukan berbagai kegiatan pengamatan dan pengumpulan data dalam pembelajaran inkuiri. Hal ini sesuai dengan pernyataan Dirman dan Juarsih (2014) bahwa pengembangan kompetensi kognitif peserta didik pada dasarnya merupakan upaya peningkatan aspek pengamatan, mengingat, berpikir, menciptakan serta kreativitas peserta didik. Untuk menciptakan daya berpikir dan mengingat yang baik diperlukan penerapan model pembelajaran yang dapat meningkatkan kompetensi siswa. Berdasarkan analisa data bahwa kompetensi pengetahuan siswa dapat meningkat dengan menggunakan model pembelajaran inkuiri terbimbing, hal ini sesuai dengan pernyataan Hosnan (2014) menyatakan pembelajaran inkuiri menekankan kepada pengembangan aspek kognitif, afektif dan psikomotor secara seimbang. Selanjutnya Putra (2013) menambahkan model pembelajaran inkuiri dapat meningkatkan potensi intelektual siswa.

Berdasarkan penelitian yang dilakukan dalam proses pembelajaran inkuiri terbimbing siswa selalu melibatkan diri dalam kegiatan bertukar pendapat melalui diskusi, pengamatan maupun kerja kelompok. Hal ini sesuai dengan pernyataan Hosnan (2014) bahwa pembelajaran inkuiri dapat membantu dalam menggunakan daya ingat dan transfer pada situasi-situasi proses belajar yang baru. 
Sedangkan Putra (2013) menyatakan proses pembelajaran inkuiri dapat membentuk dan mengembangkan konsep diri siswa. Hal ini didukung oleh penelitian yang dilakukan Sudarman (2012) bahwa implementasi (penerapan) model pembelajaran inkuiri terbimbing lebih efektif dalam meningkatkan pemahaman konsep dan kinerja ilmiah daripada penerapan pembelajaran langsung.

Hasil penelitian yang dilakukan Natalina et al. (2013) menunjukkan penerapan model pembelajaran inkuiri terbimbing dapat meningkatkan hasil belajar siswa disebabkan strategi pembelajaran inkuiri memberikan motivasi yang besar kepada siswa melalui permasalahan yang dimunculkan membuat siswa terlibat aktif dalam belajar dan tertarik dalam mendalami konsep. Peningkatan hasil belajar yang menggunakan model pembelajaran inkuiri terbimbing disebabkan karena model pembelajaran inkuiri terbimbing memberikan kesempatan kepada siswa untuk memiliki pengalaman belajar yang nyata dan aktif, siswa dilatih bagaimana memecahkan masalah sekaligus membuat keputusan. Peran guru didalam pembelajaran inkuiri terbimbing lebih sebagai fasilitator, mediator, motivator, dan evaluator (Nur \& Djirimu, 2014).

\section{Kompetensi Keterampilan (Psikomotorik)}

Hasil analisis data kompetensi keterampilan dilakukan dengan 2 penilaian keterampilan yaitu melalui keterampilan praktek dan keterampilan produk. Hasil analisa kompetensi keterampilan secara keseluruhan menunjukkan kenaikan, dari prasiklus ke siklus I mengalami peningkatan 0,44 , sedangkan perlakuan siklus I ke siklus II juga mengalami peningkatan sebesar 0,19. Peningkatan seluruh kompetensi keterampilan disajikan pada Tabel 3.

Tabel 3. Peningkatan hasil nilai rata-rata kompetensi keterampilan

\begin{tabular}{ccccc}
\hline \multicolumn{2}{c}{ Rata-rata keterampilan } & \multicolumn{2}{c}{ Peningkatan } \\
\hline Pra siklus & Siklus I & Siklus II & Prasiklus ke siklus I & Siklus I ke siklus II \\
\hline 2,68 & 3,12 & 3,31 & 0,44 & 0,19 \\
\hline
\end{tabular}

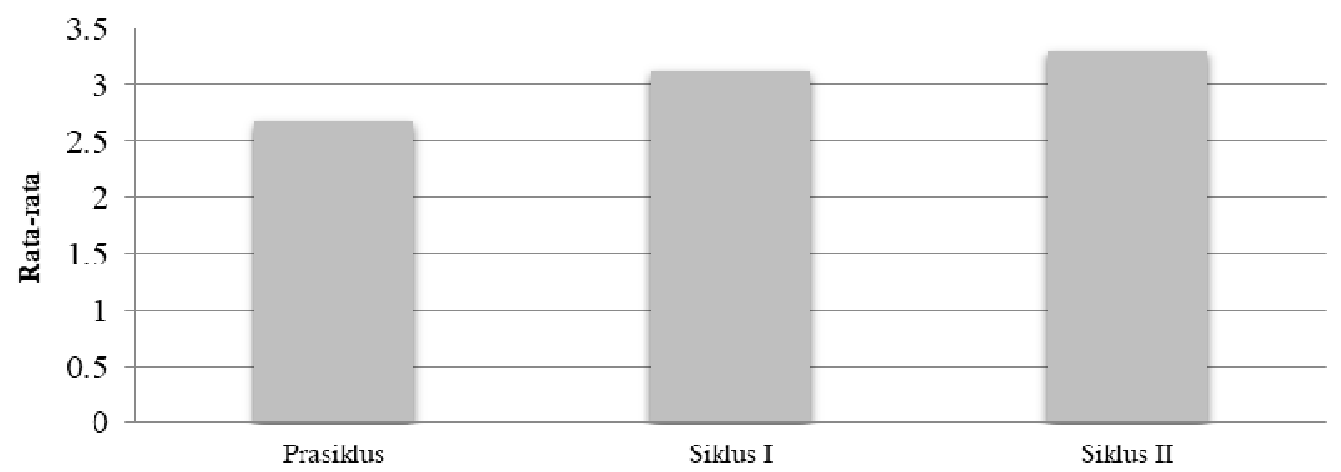

Gambar 3. Peningkatan nilai rata-rata kompetensi keterampilan dari prasiklus, siklus I dan siklus II

Hasil analisa kompetensi keterampilan secara keseluruhan menunjukkan kenaikan dari prasiklus dengan nilai rata-rata 2,68 mengalami peningkatan pada perlakuan siklus I sebesar 3,12 sedangkan perlakuan siklus II juga mengalami peningkatan 3,31. Gambar 3 menunjukkan adanya peningkatan nilai rerata keterampilan siswa dari prasiklus, siklus I dan siklus II. Hal ini dipengaruhi oleh pelaksanaan model pembelajaran dengan menggunakan 
pendekatan inkuiri terbimbing, sehingga dapat meningkatkan kompetensi keterampilan siswa dalam proses pembelajaran.

Berdasarkan hasil rata-rata kompetensi keterampilan selama menerapkan model pembelajaran inkuiri terbimbing dari prasiklus, siklus I dan siklus II menunjukkan peningkatan. Nilai rata-rata prasiklus 2,68 meningkat pada siklus I menjadi 3,12 dan pada siklus II menjadi 3,31. Hal ini membuktikan bahwa model pembelajaran inkuiri terbimbing dapat meningkatkan kompetensi keterampilan siswa. Menurut Wena (2013) yang menjelaskan bahwa esensi dari model pembelajaran inkuiri ini adalah mengajarkan kepada siswa untuk memperoleh pengetahuan seperti halnya para peneliti dalam melakukan penelitian. Sedangkan prosedurnya adalah melibatkan siswa dalam penyelidikan masalah yang sebenarnya (genuine problems) dengan cara melibatkan dalam penelitian, membantu siswa dalam mengidentifikasi konsep atau metode, dan mendorong keterampilan siswa menemukan cara untuk memecahkan masalah yang dihadapi. Kegiatan inkuiri sangat penting karena dapat mengoptimalkan keterlibatan pengalaman langsung siswa dalam proses pembelajaran (Rizal, 2014).

Berdasarkan hasil penelitian yang dilakukan oleh Dewi et al. (2013) menyebutkan bahwa model pembelajaran inkuiri terbimbing dapat memberi peluang kepada siswa untuk berpartisipasi aktif dalam proses belajar. Selanjutnya hasil penelitian Suprihatin dan Yulianti (2014) psikomotor siswa dalam pembelajaran inkuiri terbimbing pada konsep pencemaran lingkungan pada siklus I yaitu 2,29 dengan kategori $\mathrm{C}$, sedangkan pada siklus II meningkat nilai rata-rata skor sebesar 2,69 dengan kategori $\mathrm{B}$, hal ini menunjukkan penerapan aspek psikomotor siswa mulai berkembang.

\section{Aktifitas Guru}

Berdasarkan analisa aktivitas guru dalam penerapan model pembelajaran inkuiri terbimbing di kelas X IPA 2 pada pokok materi tumbuhan, menunjukkan adanya peningkatan dari prasiklus, siklus I dan siklus II. Rata-rata pada prasiklus adalah 69,23, siklus I adalah 90,47 dan siklus II adalah 100. Menurut Jufri (2013) menyatakan bahwa pendidik profesional yang memiliki kemampuan baik dalam merancang pembelajaran inkuiri terbimbing menyatakan bahwa mereka meluangkan banyak waktu untuk berinteraksi dengan peserta didik tetapi tidak banyak menunjukkan atau membantu peserta didik dalam merumuskan jawaban terhadap pertanyaan. Ini berarti bahwa pendidik yang baik akan memfasilitasi peserta didik untuk mencari dan merumuskan sendiri jawabannya terhadap permasalahan yang dihadapinya.

Hal ini sejalan dengan apa yang dikemukakan oleh Rahmayanti (2014), bahwa pembelajaran dengan model inkuiri terbimbing juga membuat suasana kelas menjadi lebih menyenangkan. Selanjutnya Yuniastuti (2013) menyatakan guru sudah menerapkan strategi pembelajaran inkuiri terbimbing dengan maksimal sehingga aktivitas meningkat. Berdasarkan hasil penelitian yang menunjukkan bahwa pemahaman konsep dan keterampilan proses sains antara siswa yang mengikuti pembelajaran model inkuiri terbimbing lebih baik daripada siswa yang mengikuti model pembelajaran langsung (Tangkas \& Made, 2012). Secara keseluruhan dapat dinyatakan dengan penerapan model inkuiri terbimbing membuat suasana belajar lebih menyenangkan, model pembelajaran inkuiri terbimbing mengajak siswa untuk belajar sambil melakukan sendiri dalam menemukan konsep yang dipelajari, berdasarkan masalah yang ada di lingkungan sekitar. 


\section{KESIMPULAN}

Berdasarkan hasil penelitian tindakan kelas dengan penerapan model pembelajaran inkuiri terbimbing dapat meningkatkan kompetensi siswa pada pokok materi klasifikasi tumbuhan di kelas X IPA 2 SMA Negeri 2 XIII Koto Kampar. Penerapan model pembelajaran inkuiri terbimbing bisa dijadikan salah satu alternatif dalam proses pembelajaran biologi terutama yang menerapkan Kurikulum 2013 dengan tujuan untuk meningkatkan kompetensi siswa.

\section{DAFTAR PUSTAKA}

Arikunto, S. (2012) Prosedur Penelitian Suatu Pendekatan Praktik. Jakarta: Bumi Aksara.

Bruce, C. (2001) Teaching Science: The Inquiry Process and Engaging in Inquiry. (Online). http://www.isrl.uiuc.edu/ chip-teach/ resources/D Process.shtml

Dewi, N. L., Dantes, N., \& Sadia, I. W. (2013). Pengaruh model pembelajaran inkuiri terbimbing terhadap sikap ilmiah dan hasil belajar IPA. PENDASI: Jurnal Pendidikan Dasar Indonesia, 3(1), 78-82

Dirman \& Juarsih, C. (2014) Pengembangan Peserta Didik. Jakarta: Rineka Cipta.

Hosnan, M. (2014). Pendekatan saintifik dan kontekstual dalam pembelajaran abad 21: Kunci sukses implementasi kurikulum 2013. Bogor: Ghalia Indonesia.

Joyce, B., Weil, M., \& Calhoun, E. (2003). Models of teaching. Massachusetts: Allyn and Bacom.

Jufri, W. (2013) Belajar dan Pembelajaran Sains. Bandung: Pustaka Reka Cipta.

Majid \& Aep (2014) Implementasi kurikulum 2013. Bandung: Interes Media.

Mustari, M. (2014) Nilai karakter Refleksi untuk Pendidikan. Jakarta: Raja Grafindo Persada.

Natalina, M., Mahadi, I., \& Suzane, A. C. (2013). Penerapan Model Pembelajaran Inkuiri Terbimbing (Guided Inquiry) untuk Meningkatkan Sikap Ilmiah dan Hasil Belajar Biologi Siswa Kelas XI IPA-5 SMA Negeri 5 Pekan Baru Tahun Ajaran 2011/2012. Prosiding Semirata FMIPA Universitas Lampung. [Online]. URL: jurnal.fmipa.unila.ac.id/index. php/semirata /article/download/591/411.[29 Maret 2014].
Novana, M., Jidan, \& Maridi. (2014) Pengembangan modul inkuiri terbimbing berbasis potensi lokal pada materi tumbuhan lumut (bryophyta) dan Tumbuhan paku (pteridophyta). Jurnal Inkuiri, 3(2), 108-122

Nur, M., Djirimu, M. L., \& Kamaluddin, K. (2014) Penggunaan Metode Inquiri Terbimbing Untuk Meningkatkan Hasil Belajar Siswa Pada Pokok Bahasan Tumbuhan Hijau di Kelas V SDN 2 Bora. Jurnal Kreatif Tadulako, 5(6), 126132

Olvah, M., \& Maulana, F. (2015). Peningkatkan Hasil Belajar Siswa Pada Konsep Sistem Regulasi Manusia Menggunakan Model Inkuiri Terbimbing. Jurnal Pendidikan Hayati, 1(1), 1622

Paidi (2009) Peningkatan Scientific Skill Siswa melalui Implementasi Metode Guided Inquiry pada Pembelajaran Biologi di SMAN I Sleman. Jurnal Teknodika UNS, 7(1)

Permendikbud No. 104 Tahun 2014 tentang Penilaian. Jakarta: Kemendikbud.

Permendikbud No. 65 Tahun 2013 tentang Standar Proses. Jakarta: Kemendikbud.

Permendikbud No. 81 A Tahun 2013 tentang Kerangka Dasar dan Stuktur Kurikulum SMA. Jakarta: Kemendikbud.

Putra, S. R. (2013) Desain Belajar Mengajar Kreatif Berbasis Sains. Yogyakarta: Diva Pres.

Rahmayanti, F., Ramdani, A., \& Japa, L. (2014). Pengaruh Penerapan Model Inkuiri Terbimbing (Guided Inquiry) terhadap kemampuan berpikir kritis siswa kelas XI Peminatan Matematika dan Ilmu-ilmu alam SMAN 2 Gerung Tahun Ajaran 2014/2015 (Skripsi, Universitas Mataram).

Rizal, M. (2014). Pengaruh Pembelajaran Inkuiri Terbimbing dengan Multi Representasi terhadap Keterampilan Proses Sains dan Penguasaan Konsep IPA Siswa SMP. Jurnal Pendidikan Sains, 2(3), 159-165.

Sudarman, I. N. (2012). Pengaruh Model Pembelajaran Inkuiri Terbimbing Terhadap Pemahaman Konsep dan Kinerja Ilmiah Siswa SMP. Jurnal Pendidikan dan Pembelajaran IPA Indonesia, 2(1), 1-19

Suprihatin, E., \& Hidayah, Y. (2014). Penerapan model pembelajaran inkuiri terbimbing pada konsep pencemaran lingkungan dalam melatih keterampilan menyelesaikan masalah siswa kelas VII MTS At-Thohiriyah. Jurnal Ilmiah Kependidikan, 9(2), 11-24.

Tangkas, I. M. (2012). Pengaruh implementasi model pembelajaran inkuiri terbimbing terhadap kemampuan pemahaman konsep dan keterampilan proses sains siswa kelas X SMAN 
Pendrice, et al. / Jurnal Pendidikan Biologi 8 (1) (2018) 20 - 30

3 Amlapura. Jurnal Pendidikan dan Pembelajaran IP A Indonesia, 2(1)

Trianto (2012) Mendesian Model Pembelajaran Inovatif-Progresif. Jakarta: Kencana Prenada Media group.

Wahyuni, E. S. (2010) Meningkatkan Hasil Belajar Siswa Sub Materi Kingdom Plantae dengan Pembelajaran Inkuiri Terbimbing di SMP. Jurnal Pendidikan dan Pembelajaran, 4(6), 1-12
Wena, M. (2013) Strategi Pembelajaran Inovatif Kontemporer. Jakarta: Bumi aksara.

Yuniastuti, E. (2016). Peningkatan keterampilan proses, motivasi, dan hasil belajar biologi dengan strategi pembelajaran inkuiri terbimbing pada siswa kelas VII SMP Kartika V-1 Balikpapan. Jurnal Penelitian Pendidikan, 13(1), 78-86 